\title{
Relationships between avian exposure, humoral immune response, and pigeon breeders' disease among Scottish pigeon fanciers
}

\author{
STEPHEN W BANHAM, CHARLES MCSHARRY, PHILLIP P LYNCH, GAVIN BOYD \\ From the Centre for Respiratory Investigation, Royal Infirmary, Glasgow
}

ABSTRACT In a large scale clinical survey of Scottish pigeon fanciers, 277 people completed a detailed questionnaire and provided a venous blood sample. There were $29(10.4 \%)$ who fulfilled the clinical criteria for pigeon breeders' disease used in the study and $84(30.3 \%)$ who showed a +


to have been sensitised. Increasing exposure was associated with a progressive tendency towards $\vec{\square}$ sensitisation, but the intensity of the antibody response was related to the presence of symptoms ando not the degree of exposure. Thirteen out of 15 subjects in the survey with a serum concentration of ${ }_{\overrightarrow{0}}$ antipigeon IgG greater than $60 \mu \mathrm{g} / \mathrm{ml}$ fulfilled the clinical criteria for pigeon breeders' disease, and $\mathscr{\infty}^{\infty}$ those affected within 10 years of starting the hobby had the highest mean antibody response. Accurate quantitation of antibody response is therefore helpful in the investigation of pigeon breed-O ers' disease. The radioimmunoassay provides a quantitative method for determining antibody response that can be used in the routine screening of pigeon fanciers and in serial monitoring of their response.

An association between pigeon breeders' disease and serum IgG antibodies to antigens derived from pigeon has been recognised since the first description of this type of hypersensitivity pneumonitis in $1965 .^{1}$ The relationship between exposure, circulating IgG antibody against pigeon protein antigens, and the development of pigeon breeders' disease remains uncertain, ${ }^{2}$ however, and this is reflected in the results of clinical studies. Patients reported in detail, ${ }^{3}$ usually with an acute, severe illness, typically have an intense antibody response and are rarely antibody negative ${ }^{4}$; whereas surveys conducted among the general population of pigeon fanciers regularly identify people who are apparently affected but who lack serum antibodies. ${ }^{56}$ Furthermore, these studies have found an appreciable proportion of healthy fanciers who do have circulating antibody against pigeon proteins, and it has been suggested that the humoral response largely reflects the intensity of exposure. ${ }^{7}$ We have

Address for reprint requests: Dr SW Banham, Centre for Respiratory Investigation, Royal Infirmary, Glasgow G4 0SF.

Accepted 23 September 1985 used a radioimmunoassay technique to investigate thehumoral antibody response and the factors whichö influence this and the development of pigeon breeders' disease in a large group of pigeon fanciers.

\section{Methods}

Pigeon fanciers in Central Scotland were approached through meetings organised at their local pigeon $₹$ racing clubs and any person regularly exposed too pigeons, whether primarily engaged in the hobby or helping a relative with the pigeon husbandry, waso asked to complete a questionnaire and provide a 20 $\mathrm{ml}$ venous blood sample. The questionnaire was di- $\%$ vided into several sections, the questions generally re- N quiring a simple "yes/no" reply. One section related w to the circumstances and degree of exposure, anothero concerned the presence of any immediate or delayed symptoms after contact with the pigeons, and a fur- $\frac{-}{D}$ ther section recorded the details of any other illnesses.? The completed questionnaires were coded and the data transferred to the disc storage of a PDP11/450 computer. Criteria for extrinsic allergic alveolitis were derived from Christensen et $a l,{ }^{6}$ requiring a delayedo (6-12 hours after exposure) respiratory symptom 
Table 1 Characteristics of all pigeon fanciers studied and of those with pigeon breeders' disease (PBD) (values are means with standard errors in parentheses)

\begin{tabular}{lcc}
\hline & All 277 & 29 with PBD \\
\hline Age (y) & $43.3(0.86)$ & $43.8((2.9)$ \\
Smoking habit (<5 pack y) & $122[44 \%]$ & $6[20.6 \%]$ \\
Asthma or hay fever* & $44[15.8 \%]$ & $5[17.2 \%]$ \\
Duration of exposure $(y)$ & $20.4(0.89)$ & $21.4(4.97)$ \\
No of pigeons kept & $46.6(1.48)$ & $49.2(4.97)$ \\
Weekly contact $(\mathrm{h}):$ & $29.6(1.13)$ & $18.7(2.34) \ddagger$ \\
Peak summer exposure & $10.6(0.55)$ & $9.1(1.26)$ \\
Winter exposure & $84[30.3 \%]$ & $21[72.4 \%]$ \\
Number sensitised & $10.9(1.86)$ & $64.6(13.5) \$$ \\
Specific $I g G(\mu \mathrm{g} / \mathrm{ml})$ &
\end{tabular}

*Personal history of asthma or hay fever not confined or relating to contact with pigeons.

†Serum concentration of $\geqslant 4 \mu \mathrm{g} / \mathrm{ml}$ of IgG antibody to pigeon gammaglobulin.

tp $<0.005$.

$\S \mathrm{p}<0.001$.

such as cough or breathlessness, and a systemic symptom, such as fever or arthralgia. Only when this had occurred at least three times, however, was the diagnosis of pigeon breeders' disease accepted. There were 32 people who completed their questionnaires incorrectly with respect to some of the questions about symptoms, but in only 15 cases were the answers uninterpretable, and in no instance did this affect the diagnosis of pigeon breeders' disease.

\section{ANTIGEN}

Pigeon serum was obtained by cardiac puncture of pigeons anaesthetised with ether. The blood was allowed to clot and the serum aspirated. The gammaglobulin fraction was then extracted by precipitation, with saturated ammonium sulphate added dropwise at $4^{\circ} \mathrm{C}$ until $40 \% \mathrm{v} / \mathrm{v}$. After an hour the precipitate was sedimented by centrifugation at 2000 $\mathrm{rev} / \mathrm{min}$ for 15 minutes, and after being washed with $40 \%$ aqueous ammonium sulphate solution and further centrifugation the precipitate was redissolved and dialysed extensively against saline. This antigen preparation was stored at $-20^{\circ} \mathrm{C}$ until use.

\section{RADIOIMMUNOASSAY}

Pigeon antigen specific IgG was measured by radioimmunoassay as developed by Nielson et al. $^{8}$ Pigeon gammaglobulin was bound to cyanogen bromide activated sepharose 4B (Pharmacia) to provide the solid phase antigen. The radiolabelled antiserum was an antihuman IgG (Scottish Antibody Production Unit, Law Hospital, Carluke) conjugated to $\mathbf{I}^{125}$ by the method of McConahey and Dixon. ${ }^{9}$ After the optimal proportions for the reagents had been established, $\mathbf{4 0} \mu \mathrm{l}$ of the patient's serum was incubated with the antigen for at least 30 minutes at room temperature. The tubes were washed three times to remove unbound protein, and the radiolabelled antiserum was added. After $\mathbf{3 0}$ minutes' incubation and extensive washing to remove unbound radioactivity the tubes were counted in a gamma counter (Gamma Set). The IgG values were obtained by interpolating the counts into a standard curve of counts from serial dilutions of a standard serum previously measured for specific IgG by quantitative precipitation. Control sera for the assay included 58 normal sera from nonexposed persons and sera from 40 patients with unrelated respiratory disorders; serum concentrations in control subjects were always less than $4 \mu \mathrm{g} / \mathrm{ml}$.

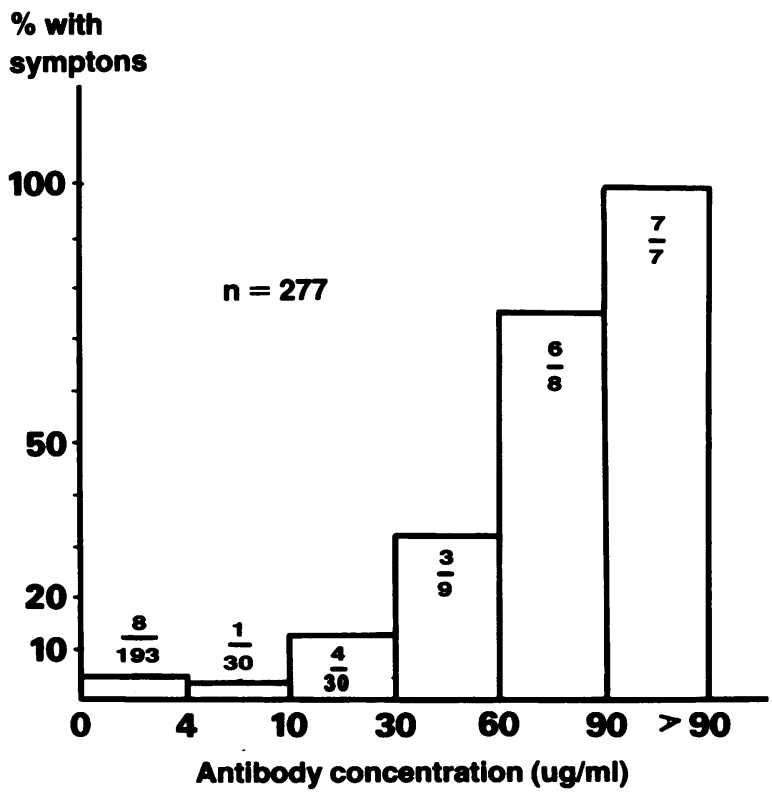

Fig 1 Proportions of subjects with pigeon breeders' disease among fanciers subdivided according to serum concentration of $\mathrm{Ig} G$ antibody to pigeon gammaglobulin $(\mu \mathrm{g} / \mathrm{ml})$. There is a highly significant association between an antibody concentration of $>60 \mu \mathrm{g} / \mathrm{ml}$ and symptoms of pigeon breeders' disease ( $\chi^{2}$ test with Yates's correction, <0.0005). 
Table 2 Mean (SE) serum antibody concentrations in 29 individuals with pigeon breeders' disease according to length of exposure before development of symptoms

\begin{tabular}{llll}
\hline $\begin{array}{l}\text { Exposure }(y) \\
\text { before } P B D\end{array}$ & $0-10$ & $11-20$ & $>20$ \\
\hline $\begin{array}{l}\text { Number } \\
\text { Specific } \\
\quad \operatorname{IgG}(\mu \mathrm{g} / \mathrm{ml})\end{array}$ & 12 & 8 & 9 \\
\hline
\end{tabular}

\section{Results}

Two hundred and seventy seven individuals were studied and most reported at least one symptom that they related to avian exposure. Where multiple symptoms were recorded many different subgroups of symptoms were evident, but there were only 29 people who fulfilled the criteria for pigeon breeders' disease. Table 1 summarises the results for the 277 pigeon fanciers studied, and compares the findings with those from the 29 with definite symptoms. Eighty four $(30.3 \%)$ of those surveyed were sensitised to pigeon gammaglobulin, but a much higher percentage $(72.4 \%)$ of the pigeon breeders' disease group had detectable antibody. An association between intensity of antibody response and pigeon breeders' disease is seen when the percentage of affected persons at increasing levels of antibody response are plotted in the form of a histogram (fig 1). There is a highly significant association between a serum antibody concentration of more than $60 \mu \mathrm{g} / \mathrm{ml}$ and the presence of pigeon breeders' disease $\left(\mathrm{p}<0.0005, \chi^{2}\right.$ test with Yates's correction).

With respect to exposure there was no difference in the degree of contact, the duration of pigeon fancying, or the number of pigeons kept between the pigeon breeders' disease group and the whole group (table 1), but the weekly contact (hours in loft) was significantly less for the 29 subjects with hypersensitivity pneumonitis ( $\mathrm{p}<0.005$, Student's $t$ test). Furthermore, among the 29 subjects with pigeon breeders' disease the subgroup affected earliest had the most vigorous antibody response (table 2 ).

For the overall study population, increasing exposure (in terms either of number of pigeons or of years exposed) was associated with a progressive tendency towards sensitisation (fig 2)-except when number of hours spent in the loft each week was the parameter of exposure (data not shown). An exposure "score" was constructed on the basis of the years of contact but modified, by the addition or subtraction of an increment of five years' exposure, according to whether the number of pigeons kept was above 60 (five years added) or below 20 (five years subtracted). Although this manoeuvre altered the distribution of fanciers over the "decades" of exposure, the relationship between degree of contact and sensitisation remains (fig 3). Furthermore, this relationship is unchanged when the pigeon breeders' disease group is 7 excluded. An increasing exposure score was not, how- 든 ever, associated with an increasingly vigorous anti- $\overline{\bar{p}}$ body response (table 3 ).

\section{Discussion}

The diagnosis of pigeon breeders' disease is most sat $-\overrightarrow{\vec{\omega}}$
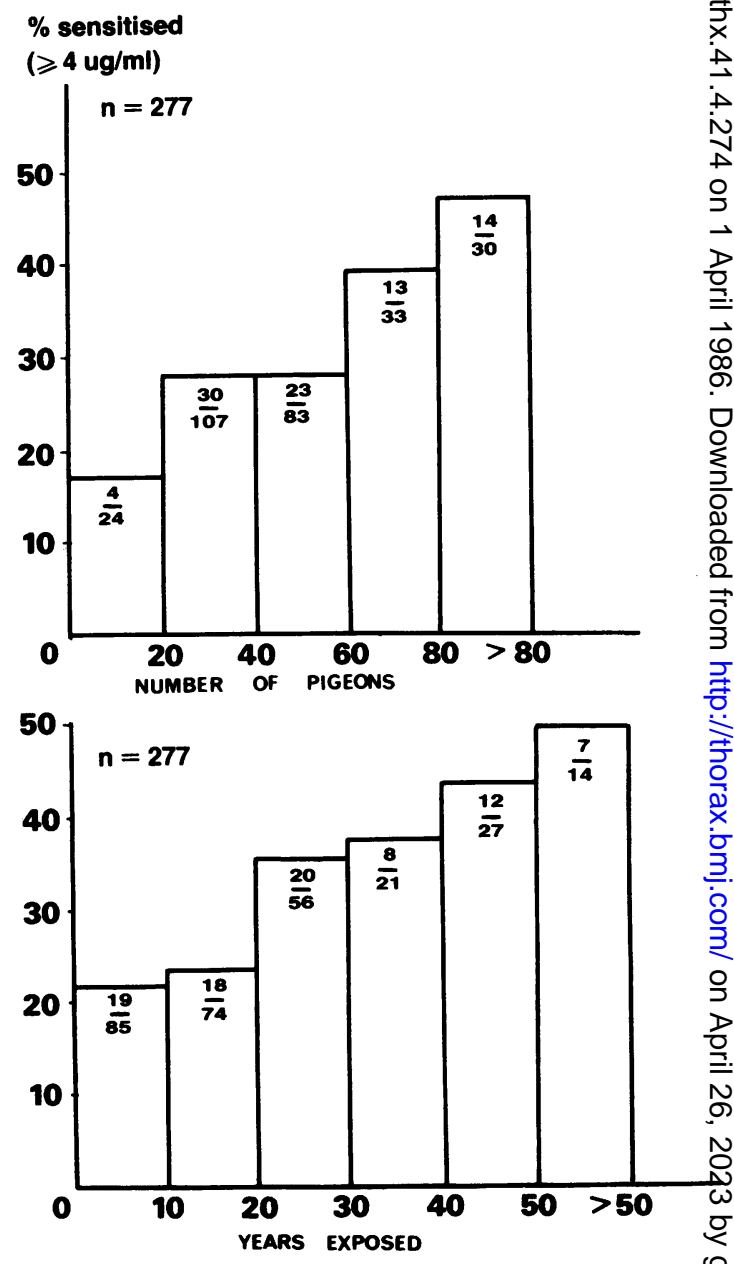

Fig 2 Proportions of pigeon fanciers sensitised (serum antibody concentration $(\geqslant 4 \mu \mathrm{g} / \mathrm{ml})$ ) among the 277 subjects subdivided according to number of pigeons kept (increments ${ }_{T}$ of 20 pigeons) and duration of exposure (decades). There is a significant association ( $\chi^{2}$ test, progression of proportions $\mathbb{R}$ between sensitisation and number of pigeons $(p<0.01)$ and $\overrightarrow{\mathbb{D}}$ decades of exposure $(p<0.005)$. 
Table 3 Distribution of antibody to pigeon gammaglobulin and serum concentrations according to exposure score

\begin{tabular}{|c|c|c|c|c|c|c|}
\hline Exposure score* & $0-10$ & $11-20$ & $21-30$ & $31-40$ & $41-50$ & $>50$ \\
\hline $\begin{array}{l}\text { Number in group } \\
\text { Number sensitised } t\end{array}$ & $\begin{array}{l}83 \\
19\end{array}$ & $\begin{array}{l}70 \\
16\end{array}$ & $\begin{array}{l}54 \\
18\end{array}$ & $\begin{array}{r}24 \\
9\end{array}$ & $\begin{array}{l}29 \\
13\end{array}$ & $\begin{array}{r}17 \\
9\end{array}$ \\
\hline $\begin{array}{l}\text { Mean (SE) specific IgG }(\mu \mathrm{g} / \mathrm{ml}) \\
\text { in those sensitised } \\
\text { Number with PBD }\end{array}$ & $\begin{array}{l}58.9(16.9) \\
12\end{array}$ & $32.8(9.5)$ & $30.8(8.4)$ & $18.6(4.9)$ & $34.6(16.2)$ & $10.8(2.3)$ \\
\hline
\end{tabular}

"See under "Results."

†Serum concentration of $\geqslant 4 \mu \mathrm{g} / \mathrm{ml}$ of IgG antibody to pigeon gammaglobulin.
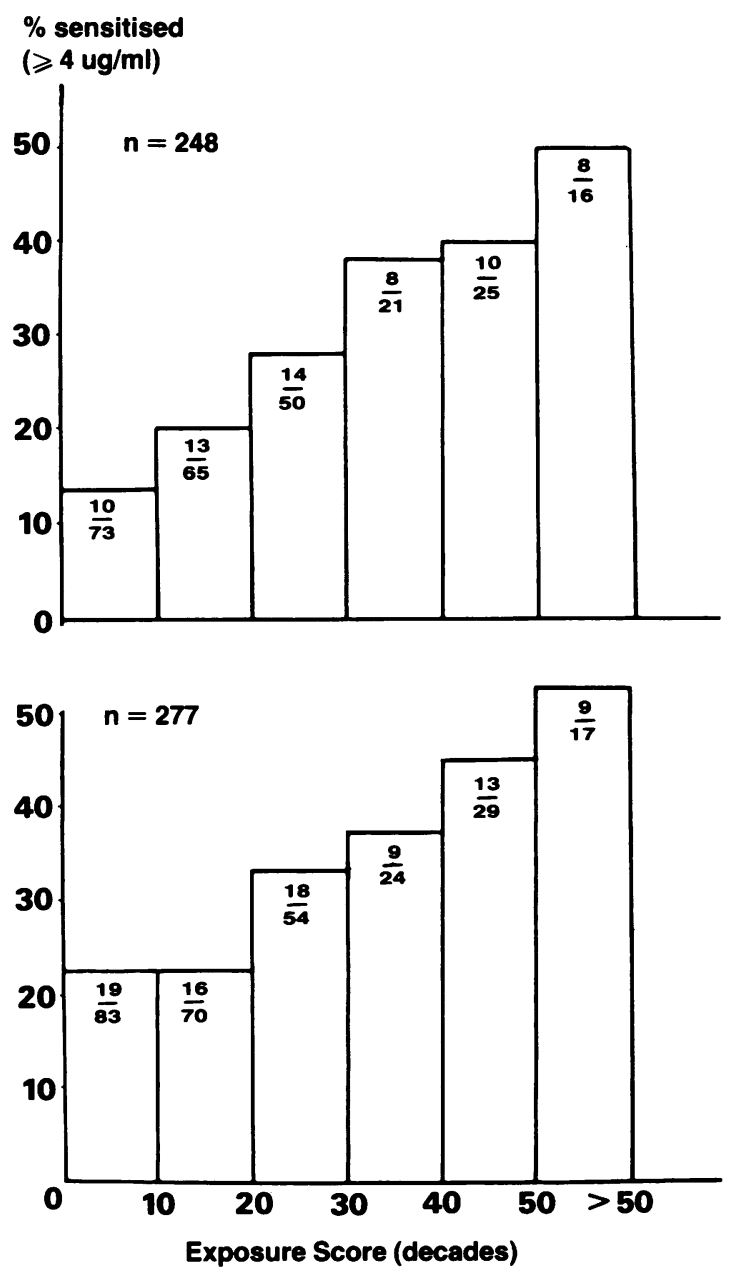

Fig 3 Proportions of pigeon fanciers sensitised (serum antibody concentration $(\geqslant 4 \mu \mathrm{g} / \mathrm{ml})$ ) in the survey population - both including (277) and excluding (248) those with pigeon breeders' disease-subdivided according to exposure score (see under "Results"). There is a significant association ( $\chi^{2}$ progression of proportions) between sensitisation and exposure score $(p<0.005$ for the 248 fanciers and $<0.001$ for the 277 fanciers). isfactorily established from a combination of clinical findings, radiographic appearances, pulmonary function assessment, and evidence of an altered immune response to pigeon protein antigens, usually the detection of serum antibodies. Differences in the diagnostic criteria applied when restricted data are available may account for some of the apparent variation in the prevalence of pigeon breeders' disease evident in reported surveys-a problem discussed by other authors. ${ }^{6}$ The simple clinical criteria adopted in the present study reduced the large number of subjects reporting some degree of clinical response to a small group considered to have experienced episodes of alveolitis-a prevalence of $10.4 \%$, which is towards the middle of the reported range. The pigeon breeders' disease group thus defined included eight antibody negative subjects, but it is important to emphasise that the grouping established on the basis of clinical information derived from a questionnaire identifies a general pattern of response and is not a precise individual classification. The main characteristic of the group remains an association with high levels of antibody to pigeon gammaglobulin, the mean antibody titre for the pigeon breeders' disease group being much higher than for the complete survey population (table 1). Sixty three pigeon fanciers $(22.7 \%)$ showed an appreciable antibody response to pigeon gammglobulin without fulfilling the criteria for pigeon breeders' disease. Since only a minority of such subjects will ever develop the disease the importance of circulating antibody has been questioned. ${ }^{10}$ Fink et $a l^{7}$ found that the presence and intensity of serum precipitins to pigeon proteins correlated with an exposure index rather than with symptoms in a survey of 200 pigeon fanciers where none described typical pigeon breeders' disease. Our findings confirm and extend the relationship between exposure and presence of specific IgG antibody. There was a progressive tendency towards sensitisation as several indices of exposure increased, although after more than 50 years' contact with pigeons half had no detectable antibody. We did not, however, find a correlation between the intensity of antibody response and increasing exposure. Rather, a vigorous antibody response was closely associated with pigeon breeders' disease and did not depend on 
intense exposure. Indeed, a subgroup consisting of the most rapidly affected fanciers (that is, the most susceptible) had the highest antibody concentration of all.

Some studies in which precipitin reactions have been graded as weak, moderate, or strong have suggested a generally more pronounced antibody response in fanciers with symptoms than in symptomless fanciers. ${ }^{11}$ This relationship is now firmly established by the present radioimmunoassay data, which furthermore suggest quantitative guidelines that might be of value in clinical management since the antibody concentration was a good indicator of "symptom status" in the survey. We found that $86.6 \%$ of those with a serum antibody concentration greater than $60 \mu \mathrm{g} / \mathrm{ml}$ described the typical symptom complex of pigeon breeders' disease.

Among the pigeon fanciers' community therefore a picture emerges in which exposure alone will gradually enlarge the proportion of sensitised pigeon fanciers, who may be considered the "at risk" group. Other factors or circumstances related to or accompanied by high concentrations of circulating antibody are required, however, before symptoms develop. In this respect those pursuing the pastime for many years are a rigorously self selected group and contrast with the subgroup who develop symptoms within 10 years of starting it. Although we found individuals who continued the pastime despite symptoms this subgroup is likely to be underrepresented in surveys. This self regulatory aspect of exposure adds to the complexity of interaction between specific immune response, exposure, and disease, which may be of particular importance in those people, most prevalent in surveys, who experience definite episodes of alveolitis without apparent progression of their disease. There is increasing evidence from animal work of a reduction in the intensity of pulmonary inflammation under certain circumstances of repeated antigen exposure where more rapid handling of antigen in the lung occurs. ${ }^{12}$ Thus tolerance is a further aspect of the immunological response that is possibly relevant to the eventual clinical outcome. Nevertheless, whatever the precise mechanism, the present findings are consistent with a role for immune complexes in the evolution of the established disease and reaffirm that the humoral aspect of extrinsic allergic alveolitis $\stackrel{\widetilde{Q}}{x}$ continues to merit attention. The radioimmunoassay $\Rightarrow$ provides a quantitative estimation of serum IgG anti- $\stackrel{-\infty}{+}$ body to pigeon gammaglobulin for identifying and? monitoring "at risk" members of the pigeon keeping 음 community.

This work was supported in part by the Scottish National Flying Club Medical Research Trust.

\section{References}

1 Reed CE, Sosman A, Barbee RA. Pigeon-breeders' lung, $\overrightarrow{-}$ a newly observed interstitial pulmonary disease. JAMA 1965;193:261-5.

2 Moore VL, Fink JN. Immunologic studies in hyper-O sensitivity pneumonitis-quantitative precipitins and complement fixing antibodies in symptomatic and asymptomatic pigeon breeders. J Lab Clin Med 1975, 85:540-5.

3 Boyd G, Dick HW, Lorimer AR, et al. Bird breeders $\overrightarrow{0}$ lung. Scot Med J 1967;12:69-71.

4 Sennekamp J, Niese D, Stroehmann I, et al. Pigeon breeders' lung lacking detectable antibodies. Clin Allergy 1978;8:305-10.

5 Elgefors B, Berlin L, Hanson LA. Pigeon breeders' lung. Scand J Respir Dis 1871;52:167-76.

6 Christensen LT, Schmidt LD, Robbins L. Pigeon breed-⿳⺈⿴囗十 ers' disease - a prevalence study and review. Clin Allergy 1975;5:417-30.

7 Fink JN, Schlueter DP, Sosman AJ, et al. Clinical survey of pigeon breeders. Chest 1972;62:277-81.

8 Nielsen KH, Parratt D, Boyd G, et al. Use of radio labelled antiglobulin for quantitation of antibody to. soluble antigens rendered particulate; application to human sera from pigeon fanciers' lung syndrome. Int Arch음 Allergy Appl Immunol 1971;47:339-43.

9 McConahey PJ, Dixon FJ. A method of trace iodinationoof proteins for immunologic studies. Int Arch Allergy Appl Immunol 1966;29:185-9.

10 Burrell R, Rylander R. A critical review of the role of precipitins in hypersensitivity pneumonitis. Eur J Resp Dis 1981;62:323-43.

11 Fink JN, Barboriak JJ, Sosman AJ. Antibodies against pigeon serum proteins in pigeon breeders. $J$ Lab Clino Med 1968;71:20-5.

12 Schnyler MR, Kleinerman J, Pensky JR, et al. Pul- N monary response to repeated exposure to Micropolyspora faeni. Am Rev Respir Dis 1983;128:1071-6. 